\title{
Effect of Indoleacetic Acid and Zinc Sulphate Application on Growth and Some Physiological Parameters of Cowpea (Vigna sinensis Savi) Plants
}

\author{
Ikbal Muhammed-Gharib Al-Barzinji \\ Department of Biology, \\ Faculty of Science and Health, \\ Koya University \\ Koya, Erbil, Iraq \\ Ikbal.tahir@koyauniversity.org
}

\author{
Sargul Ahmad Khudhur \\ Department of Biology, \\ Faculty of Science and Health, \\ Koya University \\ Koya, Erbil, Iraq \\ Sargul.khudur@koyauniversity.org
}

\author{
Arol Muhsen Anwar \\ Department of Biology, \\ Faculty of Science and Health, \\ Koya University \\ Koya, Erbil, Iraq \\ arol.anwar@koyauniversity.org
}

\begin{abstract}
This study was conducted in Koya city, Iraq on cowpea (Vigna sinensis Savi) plants California black eye variety by factorial experiment including the effects of foliar spraying of Zinc Sulphate $\mathrm{ZnSO}_{4} .7 \mathrm{H}_{2} \mathrm{O}$ $\left(Z^{S}\right)$ or the plant growth regulator Indoleacetic Acid $\mathrm{C}_{10} \mathrm{H}_{9} \mathrm{NO}_{2}\left(\mathrm{I}^{\mathrm{AA}}\right)$. Analysis of data revealed that $Z^{S}$ and $I^{A A}$ application affects significantly on the studied traits. $100 \mathrm{ppm}$ of $\mathrm{I}^{\mathrm{AA}}$ increased significantly the leaves content of each of chlorophylls $a, b$, and total, although it decreased the content of total carotenoids. The results showed that the leaf area significantly increased by increasing the amount of $Z^{S}$ to $2.0 \mathrm{~g} / \mathrm{L}$ compare with other treatments except $1.0 \mathrm{~g} / \mathrm{L} Z^{S}$ application. Foliar application of $I^{A A}$ increased significantly the dry matter percent of shoots and roots as well as the number of nodules per plant. It has been found that leaves content of zinc is related to the concentration of $Z^{S}$ applied significantly compared to the control and $I^{A A}$ treatments, however the application of $I^{A A}$ caused to decrease $K$ and $\mathrm{Zn}$ contents in leaf of the plants compared to other treatments. Finally, based on the results the best ratio of $I^{A A}$ for increased stomata number on the abaxial and adaxial leaves surfaces was 75 ppm.
\end{abstract}

Keywords: Cowpea, Chlorophylls, $I^{A A}$, Stomata, $Z^{\mathrm{S}}$.

\section{INTRODUCTION}

Cowpea plant is a summer crop considered an important crop in Iraq which is cultivated for their green pods or/and their dry seeds in all Iraqi regions; it belongs to Fabaceae family [1].

It is well known that nutrient elements are very vital for physiological and biochemical processes in plants. The use of plant elements as nutrition has a wide application all over the worldwide including Iraq. Zinc is an important micro-elements used in these fields, for example, using zinc at $0,5,10$ and $15 \mathrm{~kg} / \mathrm{ha}$ as $\mathrm{ZnSO}_{4}$ increased significantly each of plant height, branches, leaves, dry matter, effective nodules weight and plant grain yield of cowpea (Vigna unguiculata) [2]. In a study [3], application of $\mathrm{ZnSO}_{4}$ at $25 \mathrm{~kg}$ / ha through soil or as a single spray of $0.5 \% \mathrm{ZnSO}_{4}$ either at 25 or 45 days after sowing (DAS) or two sprays of $0.5 \% \mathrm{ZnSO}_{4}$ at 25 and 45 DAS were seen effective increasing in cowpea (Vigna unguculata L. Walp) plant high, number of branches and yield components compared to the control treatment. Also, it is found that zinc application increased the grain yield of pea (Vigna radiate) as a result of auxin synthesis, nodules performing, and nitrogen fixation, which leads to estimating plant growth, and development, thus influenced the grain yield positively [4]. The best response of zinc application (2.5kg/ha and $5 \mathrm{~kg} / \mathrm{ha})$ on plant growth parameters including plants height, number of nodules/plant, number of branches/plant and plant dry weight due to zinc effect on the metabolism of growing plants, which may effectively explain the observed response of zinc application [5], whereas [6] reported that foliar spray application at $1.5 \% \mathrm{ZnSO}_{4}$ plays a significant role in increasing cowpea growth parameters when applied with $2 \%$ urea.

Another application used widely in agriculture is plant growth regulators which have great advantages for improving the growth, development and crops productivity. The phytohormone auxin is used nowadays on the plants for change their response toward different physiological processes, auxin is an important regulator for many aspects of plant growth and development, it promote cell elongation and division in stem, differentiation, tropisms and apical dominance, whereas it inhibits root growth, bud formation, senescence and leaves and fruits abscissions [7,8]. The major natural auxin is indole-3-acetic acid $\left(\mathrm{I}^{\mathrm{AA}}\right)$. There are three major classes of synthetic auxins, the first one is the aryl acetic acids, which include indoleacetic acid $\left(\mathrm{I}^{\mathrm{AA}}\right)$ itself [9]. The phytohormone auxin is affected by several factors including the microelement zinc, which is considered as a stimulating for auxin synthesis. For instance, in plants growing in a medium deficient of zinc, the stem fails to elongate and fail of leaves to expand to the normal and mature size, and elongation of the stem is almost reduced. Growth forms can stunt when zinc elements inefficient [10].

The aim of this study was to make a comparison between $\mathrm{Z}^{\mathrm{S}}$ salt and the auxin $\mathrm{I}^{\mathrm{AA}}$ on the growth and some physiological characteristics of cowpea plants. 


\section{METHODS AND MATERIALS}

\subsection{Plant material and treatments}

Cowpea (Vigna sinensis Savi) var. California black eye seeds were planted in the Faculty of Science and Health, Koya University, Erbil-Iraq ( $44^{\circ} 38 \mathrm{E}, 36^{\circ} 4 \mathrm{~N}$ and $517 \mathrm{~m}$ of altitude), and a randomized complete block design (RCBD) were conducted by using foliar spraying of one of the following solutions: distilled water (control), 0.5, 1.0 or $2.0 \mathrm{~g} / \mathrm{L}$ of $\mathrm{Z}^{\mathrm{S}}$ salt or 50,75 or $100 \mathrm{ppm}$ of the plant growth regulator $\mathrm{I}^{\mathrm{AA}}$.

\subsection{Studies characteristics}

At the end of the stage of vegetative growth three separated plants were harvested from each experimental unit, and the following characteristics were determined: pigments of chlorophylls a, chlorophyll b and total carotenoids are calculated as it mention by [11] by taking pre-weighted samples with extracting by acetone with 1:50 extraction ratio. The samples were grained using pestle and mortar and then filtered by filter paper. The supernatants were speared and the concentration of the pigments was measured spectrophotometrically (7212000 SPECTROPHOTOMETER, China). The amount of pigments presented in each sample was calculated according to the following equations, each of chlorophyll-a, b and total carotenoids content in fresh materials were determined.

$$
\begin{gathered}
\text { Chl. }_{. \mathrm{a}}=11.75 \mathrm{~A}_{662}-2.35 \mathrm{~A}_{645} \\
\text { Chl. }_{. \mathrm{b}}=18.61 \mathrm{~A}_{645}-3.96 \mathrm{~A}_{662} \\
\text { Car. }=1000 \mathrm{~A}_{470}-2.27 \mathrm{Chl}_{. \mathrm{a}}-81.4 \mathrm{Chl} . \mathrm{b} / 227
\end{gathered}
$$

where $\mathrm{A}=$ Absorbance, Chl. ${ }_{\text {a }}=$ chlorophyll a $[\mathrm{mg} / \mathrm{L}]$, Chl.b = chlorophyll b [mg/L], Car. = Total carotenoids $[\mathrm{mg} / \mathrm{L}]$, then for converting the concentrations from $\mathrm{mg} / \mathrm{L}$ to $\mathrm{mg} / \mathrm{g}$ fresh weight, each value multiplied by (extraction volume/ (sample weight*1000)). Leaf area was calculated by the method that described by [12] by spreading each leaf over a paper, and the outline of the leaf was drawn. By using a scissor, the area of the paper covered by the outline was cut and weighed on an electronic balance. One $\mathrm{cm}^{2}$ of the same paper was also cut and weighed. The following equation was used to calculate the leaf area: Leaf area $\left(\mathrm{cm}^{2}\right)=x / y$, where $\mathrm{x}$ is the weight of the paper covered by the leaf outline (g) and $\mathrm{y}$ is the weight (g) of the $\mathrm{cm}^{2}$ area of the paper. The percent of shoot, root, and nodules dry matter were calculated as it described by [13] by dividing the dry weight of leaves or roots or nodules samples by the wet weight of them multiplied by 100 , number of nodules per plant, total potassium determined by using flame photometer as it mentioned by [14], total zinc determined by using atomic absorption spectrophotometer by using acetylene gas at $213.9 \mathrm{~nm}$ [15], number, length, and width of stomata in the adaxial and abaxial leaf surfaces measured by the method of lasting impressions [16] by painting approximately 1 $\mathrm{cm}^{2}$ of leaves surfaces by transparent nail polish. When the nails polish was dried, a piece of transparent tape was stick to the dried nail, and peeled out gently, to represent the leaf impression that contains the stomata apertures which were putted on slides to represent the abaxial and adaxial leaves surfaces. 400x magnifications were used to examine the leaf impressions by light microscope. Stomata numbers were counted per $\mathrm{mm}^{2}$ area. Leaf stomata length and width were measured in micrometer by an ocular micrometer.

\subsection{The statistical analysis}

An experiment was performed by randomized complete block design (RCBD) with three replications was used in this study to test main effects. The differences among treatments were investigated by analysis of variance (ANOVA) using SAS program [17]. The Duncan`s multiple comparison test was used to evaluate the main effects of treatments that differed when the F-value was significant at $\leq 0.05$.

\section{RESULTS AND DISCUSSION}

Analysis of data revealed that $\mathrm{Z}^{\mathrm{S}}$ and $\mathrm{I}^{\mathrm{AA}}$ application effects significantly on the studied traits. The results in Table 1 show that the foliar spraying with 100 ppm IAA increased significantly the leaves content of each of chlorophyll a, chlorophyll b and total chlorophylls to 5.77, 5.94 and $11.71 \mathrm{mg} / \mathrm{g}$ fresh weight compared to the control and $0.5 \% \mathrm{Z}^{\mathrm{S}}$ for chlorophyll a and in addition to $50 \mathrm{ppm} \mathrm{I}^{\mathrm{AA}}$ for chlorophyll b and total chlorophylls. Applying $\mathrm{Z}^{\mathrm{S}}$ and $\mathrm{I}^{\mathrm{AA}}$ treatments decreased leaves content of total carotenoids where the control treatment recorded the highest value reached $1.16 \mathrm{mg} / \mathrm{g}$ fresh wet followed by the lowest concentration of $\mathrm{Z}^{\mathrm{S}}$ and $\mathrm{I}^{\mathrm{AA}}$ which were 1.14 and $1.11 \mathrm{mg} / \mathrm{g}$ fresh wet respectively. The increase in chlorophylls content at the highest concentration of $\mathrm{I}^{\mathrm{AA}}$ may due to the role of auxin in synthesizing chlorophyll and plastids development, whereas it decreased the carotenoids content as it mentioned by [18], zinc ions are required for many enzymes for completion their activities, also zinc may be required in some plants for chlorophyll biosynthesis [19].

From the results shown in Table 2, it appears that increasing the concentration of $\mathrm{Z}^{\mathrm{S}}$ to $2.0 \mathrm{~g} / \mathrm{L}$ increased significantly the plant`s leaf area to $3281.9 \mathrm{~cm}^{2}$ in comparison with other treatments except for the treatment $1.0 \mathrm{~g} / \mathrm{L}$ of $\mathrm{Z}^{\mathrm{S}}$. Increasing plant leaf area with increasing $\mathrm{Z}^{\mathrm{S}}$ concentration due to micronutrients generally increase the area of leaves, so more assimilate in the plant will produce [20], in addition to the role of zinc in activating many enzymes, like tryptophan synthetase superoxide dismutase and dehydrogenases [5], enolase and peptidase and it has an important role in synthesizing the amino acid tryptophan which is a necessary material for tryptophan-dependent $\mathrm{I}^{\mathrm{AA}}$ biosynthetic pathway in the chloroplast [21, 22].The effect of zinc sulphate compared to the $\mathrm{I}^{\mathrm{AA}}$ is that zinc encouraged the graduate synthesizing of $\mathrm{I}^{\mathrm{AA}}$ which is oxidizedenzymatically or by light.

Recently the zinc metallo proteins which are a new class of zinc-dependent protein molecules identified in the replication and transcription of DNA, and as a result regulates gene expression [23, 24]. [25] attributes the low level of $\mathrm{I}^{\mathrm{AA}}$ in plants poor of zinc caused by inhibiting their synthesis. 
Table 1: Effects of foliar spraying with $\mathrm{Z}^{\mathrm{S}}$ and $\mathrm{I}^{\mathrm{AA}}$ on chlorophyll a, b, total carotenoids of cowpea leaves.

\begin{tabular}{|c|c|c|c|c|}
\hline \multirow{3}{*}{ Treatments } & \multicolumn{3}{|c|}{ Chlorophyll } & \multirow{2}{*}{$\begin{array}{c}\text { Total } \\
\text { carotenoids }\end{array}$} \\
\hline & $\mathbf{a}$ & $\mathbf{b}$ & Total & \\
\hline & \multicolumn{4}{|c|}{ mg/g fresh weight } \\
\hline Control & $4.51^{b}$ & $3.54^{\mathrm{c}}$ & $8.05^{c}$ & $1.16^{\mathrm{a}}$ \\
\hline $\begin{array}{c}\mathrm{Z}^{\mathrm{S}} \\
(0.5 \mathrm{~g} / \mathrm{L})\end{array}$ & $4.73^{b}$ & 3.96 bc & 8.69 bc & $1.14^{\mathrm{ab}}$ \\
\hline $\begin{array}{c}Z^{\mathrm{S}} \\
(1.0 \mathrm{~g} / \mathrm{L})\end{array}$ & $5.44^{a b}$ & $5.64^{\mathrm{a}}$ & 11.09 ab & 0.89 bc \\
\hline $\begin{array}{c}Z^{\mathrm{S}} \\
(2.0 \mathrm{~g} / \mathrm{L})\end{array}$ & $5.43^{a b}$ & $5.06^{a b}$ & $10.48^{\mathrm{abc}}$ & $0.97 \mathrm{abc}$ \\
\hline $\begin{array}{c}\mathrm{I}^{\mathrm{AA}} \\
(50 \mathrm{ppm})\end{array}$ & $5.04^{a b}$ & 3.74 bc & 8.79 bc & $1.11^{\mathrm{ab}}$ \\
\hline $\begin{array}{c}\mathrm{I}^{\mathrm{AA}} \\
(75 \mathrm{ppm})\end{array}$ & $5.27 \mathrm{ab}$ & $4.70 \mathrm{abc}$ & $9.97 \mathrm{abc}$ & $0.99 \mathrm{abc}$ \\
\hline $\begin{array}{c}\mathbf{I}^{\mathrm{AA}} \\
(100 \mathrm{ppm})\end{array}$ & $5.77^{\mathrm{a}}$ & $5.94^{\mathrm{a}}$ & $11.71^{\mathrm{a}}$ & $0.85^{c}$ \\
\hline
\end{tabular}

Means in the same column followed by the same symbol are not significantly different at $p \leq 0.05$ level based on Duncan test.

From the same table, we see that foliar spraying with $\mathrm{I}^{\mathrm{AA}}$ increased significantly shoot dry matter percent as compared to the control (Table 2), which may due to decreasing their leaf area which leads to concentrate the photosynthates in less area and increasing their dry matter. Increasing the concentration of $\mathrm{I}^{\mathrm{AA}}$ increased the root dry matter percent significantly compared to other treatments. Spraying IAA increase the root development which reflects positively on water and nutrition absorption, and as a result increasing plant growth characteristics [26], especially the shoot and root dry matter. This result agrees with that of [27] whom reported that foliar spraying by 25 and $50 \mathrm{mg} / \mathrm{L}$ of $\mathrm{I}^{\mathrm{AA}}$ increased each of plant height, shoot dry weight, number of leaves and branches compared to the control treatment, whereas $100 \mathrm{mg} / \mathrm{L}$ decreased these characteristics compared to the control treatment.

Increasing the $\mathrm{I}^{\mathrm{AA}}$ concentration to $100 \mathrm{ppm}$ increased the number of nodules per plant significantly to 10.67 nodules/plant compared only to 6.67 nodules per plant for the $2 \mathrm{~g} / \mathrm{L} \mathrm{Z}$ treatment which increased the percent of nodules dry matter significantly to $69.39 \%$ in compared to $75 \mathrm{ppm} \mathrm{I}^{\mathrm{AA}}$ and $1 \mathrm{~g} / \mathrm{L} \mathrm{Z^{ \textrm {S } }}$ that records 55.60 and $57.50 \%$ respectively. This increase in nodules number in $100 \mathrm{ppm} \mathrm{I}^{\mathrm{AA}}$ treatment may due to $\mathrm{I}^{\mathrm{AA}}$ is playing an essential role in nodule and nodule bacteria for the nodule development and symbiotic relationship between that plant and these bacteria [28]. Also, agree with the results of [29] who stated that rhizobial I ${ }^{\mathrm{AA}}$ biosynthesis increased number of nodules/ plant in Medicago truncatula and $M$. sativa plants that nodulated with Sinorhizobium meliloti bacteria which is engineered genetically to increase the synthesis of $\mathrm{I}^{\mathrm{AA}}$ auxin or control strain.[30] reported that the root nodules of black gram Phaseolus mungo plants are considered as tryptophan pool which have a role in indoleacetic acid synthesis, when the synthesis of $\mathrm{I}^{\mathrm{AA}}$ increased in the treatment of supplementing of l-tryptophan by $2 \mathrm{mg} / \mathrm{mL}$ by the symbiont compared to the control treatment.

The results of Table 3 show that leaves content of total potassium increased significantly to 180.67 when $1.0 \mathrm{~g} / \mathrm{L}$
$\mathrm{Z}^{\mathrm{S}}$ was applied compared to other treatments, however applying $\mathrm{I}^{\mathrm{AA}}$ decreased the percent of total potassium significantly especially the high concentrations 75 and $100 \mathrm{ppm}$. The increase in potassium concentration in 1 $\mathrm{g} / \mathrm{L} \mathrm{Z} \mathrm{Z}^{\mathrm{S}}$ treatment may due to the synergistic relationship between sulfur and potassium ions, which determined in several studies [19]. The decrease in potassium and zinc concentration with increasing $\mathrm{I}^{\mathrm{AA}}$ may due to high concentration was used, this result does not agree with the results of [31] who stated an increase in cowpea leaves content of these elements when sprayed with $\mathrm{I}^{\mathrm{AA}}$ at 12.5, 25 and $50 \mathrm{ppm}$, which were low concentrations compared to ours.

Table 2: Effects of foliar spraying with $\mathrm{Z}^{\mathrm{S}}$ and $\mathrm{I}^{\mathrm{AA}}$ on some of the vegetative growth characteristics of cowpea plants.

\begin{tabular}{|c|c|c|c|c|c|}
\hline Treatments & $\begin{array}{l}\text { Leaf } \\
\text { area } \\
\left(\mathrm{cm}^{2}\right)\end{array}$ & $\begin{array}{c}\begin{array}{c}\text { Shoot } \\
\text { dry }\end{array} \\
\text { matter } \\
(\%)\end{array}$ & $\begin{array}{c}\text { Root } \\
\text { dry } \\
\text { matter } \\
(\%) \\
\end{array}$ & $\begin{array}{c}\text { Number } \\
\text { of } \\
\text { nodules/ } \\
\text { plant }\end{array}$ & $\begin{array}{c}\text { Nodules } \\
\text { dry } \\
\text { matter } \\
(\%)\end{array}$ \\
\hline Control & $2022^{b}$ & $18.72^{\mathrm{c}}$ & $24.67^{\text {cd }}$ & $8.33^{\mathrm{ab}}$ & $66.70^{\mathrm{ab}}$ \\
\hline $\begin{array}{c}Z^{\mathrm{S}} \\
(0.5 \mathrm{~g} / \mathrm{L})\end{array}$ & $1837^{b}$ & $20.06^{\mathrm{ab}}$ & $24.37^{\mathrm{cd}}$ & $8.33^{\mathrm{ab}}$ & $61.97^{\mathrm{abc}}$ \\
\hline $\begin{array}{c}Z^{S} \\
(1.0 \mathrm{~g} / \mathrm{L})\end{array}$ & $2550^{\mathrm{ab}}$ & $19.55^{\mathrm{bc}}$ & $22.72^{d}$ & $8.67^{\mathrm{ab}}$ & $57.50^{\mathrm{bc}}$ \\
\hline $\begin{array}{c}Z^{\mathrm{S}} \\
(2.0 \mathrm{~g} / \mathrm{L})\end{array}$ & $3281^{\mathrm{a}}$ & $21.16^{\mathrm{ab}}$ & $26.52^{\mathrm{bc}}$ & $6.67^{\mathrm{b}}$ & $69.39^{\mathrm{a}}$ \\
\hline $\begin{array}{c}I^{\mathrm{AA}} \\
(50 \mathrm{ppm})\end{array}$ & $1753^{\mathrm{b}}$ & $20.94^{\mathrm{ab}}$ & $27.62^{\mathrm{ab}}$ & $9.33^{\mathrm{ab}}$ & $62.80^{a b c}$ \\
\hline $\begin{array}{c}\mathrm{I}^{\mathrm{AA}} \\
(75 \mathrm{ppm})\end{array}$ & $1799^{\mathrm{b}}$ & $21.40^{\mathrm{a}}$ & $28.92^{\mathrm{ab}}$ & $8.67^{\mathrm{ab}}$ & $55.60^{c}$ \\
\hline $\begin{array}{c}\mathrm{I}^{\mathrm{AA}} \\
(100 \mathrm{ppm})\end{array}$ & $1706^{\mathrm{b}}$ & $20.94^{\mathrm{ab}}$ & $30.12^{\mathrm{a}}$ & $10.67^{a}$ & $59.21^{a b c}$ \\
\hline
\end{tabular}

Means in the same column followed by the same symbol are not significantly different at $\mathrm{p} \leq 0.05$ level based on Duncan test.

From the results of Table 3 it is appear that zinc concentration increased significantly with increasing the $\mathrm{Z}^{\mathrm{S}}$ concentration where the leaves content of zinc increased to $1.57,1.77$ and $2.27 \mathrm{ppm}$ with increasing the concentration of $\mathrm{Z}^{\mathrm{S}}$ from 0.5 to $2 \mathrm{~g} / \mathrm{L}$ significantly compared to the control and all $\mathrm{I}^{\mathrm{AA}}$ concentrations. The general decrease in $\mathrm{Zn}$ concentration in plant leaves for all treatments including the control may due to increasing the $\mathrm{K}$ concentration, where [32] reported that macronutrient cations such as calicium, magnesium and potassium inhibit the absorption of zinc by plants from solutions.

Regarding potassium concentration, it has both positive and negative interaction effects as it has shown in Table 3, where increasing zinc concentration increased potassium concentration in leaves, which agree with [33] who stated that zinc interacts positively with potassium, whereas in this study, also the negative effect was appeared when the concentration of zinc increased to $2 \mathrm{~g} / \mathrm{L}$ which leads to decreasing potassium concentration. 
Table 3: Effects of foliar spraying with $\mathrm{Z}^{\mathrm{S}}$ and $\mathrm{I}^{\mathrm{AA}}$ on leaves content of total potassium and zinc of cowpea leaves.

\begin{tabular}{|c|c|c|}
\hline Treatments & $\begin{array}{c}\text { Total potassium } \\
\text { (ppm) }\end{array}$ & $\begin{array}{c}\text { Total zinc } \\
\text { (ppm) }\end{array}$ \\
\hline Control & $151.33^{\mathrm{b}}$ & $0.73^{b}$ \\
\hline $\mathrm{Z}^{\mathrm{S}}(0.5 \mathrm{~g} / \mathrm{L})$ & $148.33^{b}$ & $1.57^{\mathrm{a}}$ \\
\hline $\mathrm{Z}^{\mathrm{S}}(1.0 \mathrm{~g} / \mathrm{L})$ & $180.67^{a}$ & $1.77^{\mathrm{a}}$ \\
\hline $\mathrm{Z}^{\mathrm{S}}(2.0 \mathrm{~g} / \mathrm{L})$ & $114.67^{c}$ & $2.27^{\mathrm{a}}$ \\
\hline $\mathrm{I}^{\mathrm{AA}}(50 \mathrm{ppm})$ & $135.00^{\text {bc }}$ & $0.60^{b}$ \\
\hline IAA $^{\mathrm{AA}}$ (75 ppm) & $52.33^{d}$ & $0.65^{b}$ \\
\hline $\mathrm{I}^{\mathrm{AA}}(100 \mathrm{ppm})$ & $52.67^{d}$ & $0.53^{b}$ \\
\hline
\end{tabular}

Means in the same column followed by the same symbol are not significantly different at $\mathrm{p} \leq 0.05$ level based on Duncan test.

From the results of Table 4 and Figure 1 and 2, it appears that using $75 \mathrm{ppm}$ of $\mathrm{I}^{\mathrm{AA}}$ increased stomata number on the abaxial and adaxial leaves surfaces compared to other treatments, whereas this treatment decreased stomata lengths significantly compared to other treatments for abaxial leaves surfaces. From the same table, it is shown that increasing the concentration of zinc and auxin decreased stomata lengths significantly on the adaxial leaves surfaces (Table 4). Decreasing stomata length significantly in the 0.5 and $1 \mathrm{~g} / \mathrm{L}$ may due to increasing the potassium concentrations in guard cells (Table 3) which leads to increase osmotic solute that results in water uptake into the guard cells [14]. Neither $\mathrm{Z}^{\mathrm{S}}$ nor $\mathrm{I}^{\mathrm{AA}}$ had significant effects on stomata width for different treatments on each of abaxial and adaxial leaves surfaces. The results are in line with [34] and [35] who reported that the characteristics of stomata such as number, length and width is affected by several factors viz. genetic constituents, ecological condition, environmental factors, season, physiological process, leaf position and leaf surface.

Table 4: Effects of foliar spraying with $\mathrm{Z}^{\mathrm{S}}$ and $\mathrm{I}^{\mathrm{AA}}$ on stomata number, length and width for cowpea leaves.

Means in the same column followed by the same symbol are not

\begin{tabular}{|c|c|c|c|c|c|c|}
\hline \multirow{2}{*}{ } & \multicolumn{2}{|c|}{$\begin{array}{c}\text { Stomata } \\
\text { number } / \mathrm{mm}^{2}\end{array}$} & \multicolumn{2}{|c|}{$\begin{array}{c}\text { Stomata } \\
\text { length } \\
\text { (micrometer) } \\
\end{array}$} & \multicolumn{2}{|c|}{$\begin{array}{c}\text { Stomata } \\
\text { width } \\
\text { (micrometer) }\end{array}$} \\
\hline & 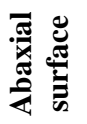 & 䒝 & 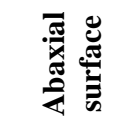 & 矛 & 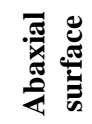 & 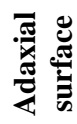 \\
\hline Control & $400^{d}$ & $240^{\mathrm{bc}}$ & $10.0^{\mathrm{ab}}$ & $12.0^{\mathrm{a}}$ & $7.0^{\mathrm{a}}$ & $4.0^{\mathrm{a}}$ \\
\hline $\begin{array}{l}\mathrm{Z}^{\mathrm{S}} \\
(0.5 \mathrm{~g} / \mathrm{L})\end{array}$ & $676^{\mathrm{ab}}$ & $270^{b}$ & $10.0^{\mathrm{ab}}$ & $10.0^{\mathrm{b}}$ & $8.0^{a}$ & $4.0^{\mathrm{a}}$ \\
\hline $\begin{array}{l}Z^{S} \\
(1.0 \mathrm{~g} / \mathrm{L})\end{array}$ & $660^{\mathrm{b}}$ & 250 bc & $10.0^{\mathrm{ab}}$ & $8.0^{c}$ & $7.0^{\mathrm{a}}$ & $3.0^{\mathrm{a}}$ \\
\hline $\begin{array}{l}Z^{S} \\
(2.0 \mathrm{~g} / \mathrm{L})\end{array}$ & $630^{\mathrm{b}}$ & $223^{c}$ & $9.0^{\mathrm{bc}}$ & $9.0^{b c}$ & $6.0^{\mathrm{a}}$ & $4.0^{\mathrm{a}}$ \\
\hline $\begin{array}{l}\text { I } \\
(50 \text { ppm) }\end{array}$ & $600^{b}$ & $260^{b}$ & $11.0^{\mathrm{a}}$ & $12.0^{\mathrm{a}}$ & $8.0^{\mathrm{a}}$ & $4.0^{\mathrm{a}}$ \\
\hline $\begin{array}{l}\text { IAA } \\
\text { (75 ppm) }\end{array}$ & $750^{a}$ & $343^{a}$ & $8.0^{c}$ & $9.0^{b c}$ & $6.0^{\mathrm{a}}$ & $4.0^{\mathrm{a}}$ \\
\hline $\begin{array}{l}\text { IAA } \\
\text { (100 ppm) }\end{array}$ & $480^{c}$ & $220^{c}$ & $11.0^{\mathrm{a}}$ & $8.0^{\mathrm{c}}$ & $8.0^{a}$ & $3.0^{\mathrm{a}}$ \\
\hline
\end{tabular}

significantly different at $\mathrm{p} \leq 0.05$ level based on Duncan test.

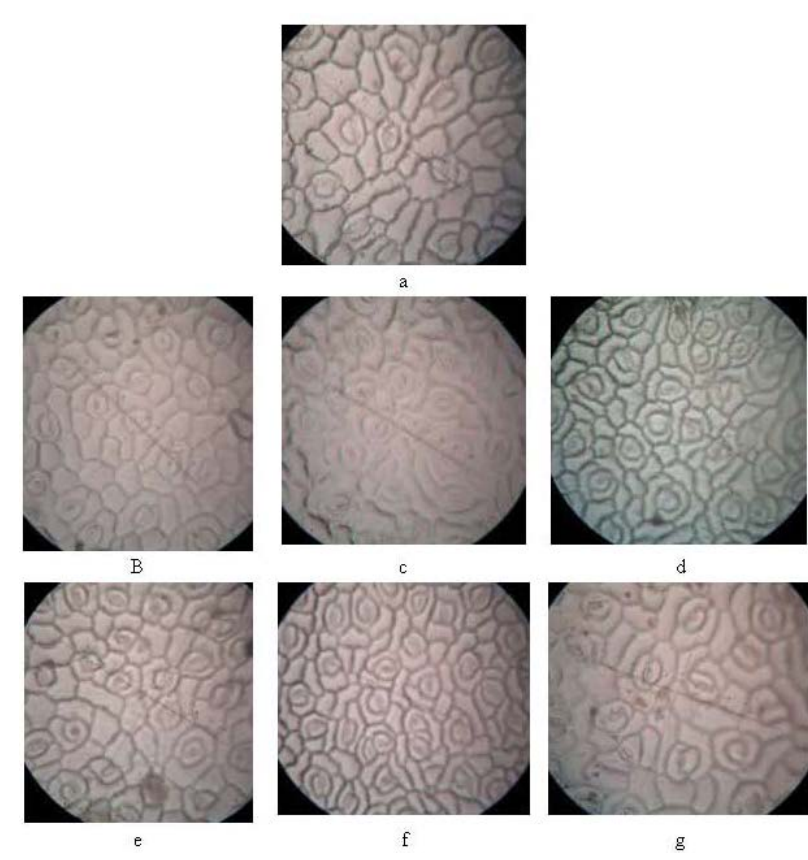

Figure 1: Stomata of upper (adaxial) leaves surfaces of Vigna sinensis Savi at 400X for plants of the: (a) control (b) 0.50 (c) 1.00 (d) $2.0 \mathrm{~g} / \mathrm{L} \mathrm{Z}^{\mathrm{S}}$ (e) 50 (f) 75 (g) $100 \mathrm{ppm} \mathrm{I}^{\mathrm{AA}}$ treatments.
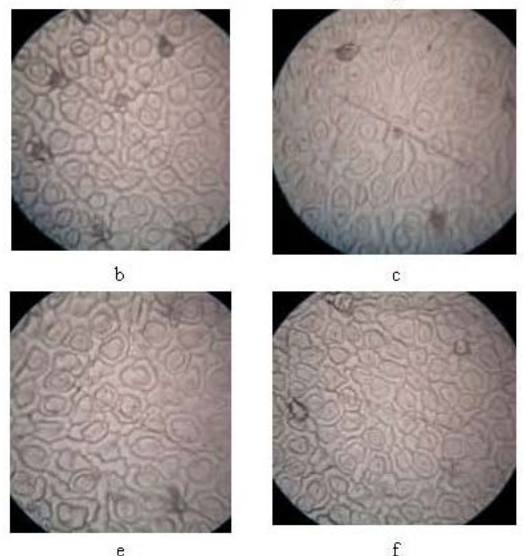
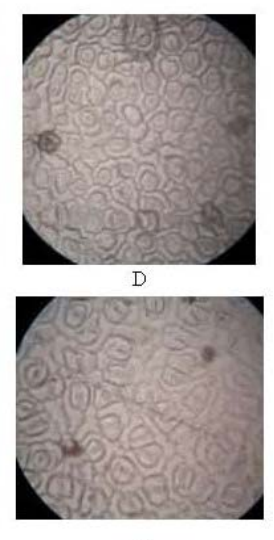

G
Figure 2: Stomata of lower (abaxial) leaves surfaces of Vigna sinensis Savi. At 400X for plants of the:(a) control (b) 0.50 (c) 1.00 (d) $2.0 \mathrm{~g} / \mathrm{L} \mathrm{ZnSO}_{4}(\mathrm{e}) 50 \mathrm{I}^{\mathrm{AA}}$ (f) 75 (g) 100 ppm I ${ }^{\mathrm{AA}}$ treatments.

\section{CONCLUSION}

This study results showed that the application of foliar spraying of the salt, $\mathrm{Z}^{\mathrm{S}}$ and the auxin $\mathrm{I}^{\mathrm{AA}}$ had a significant effects on the characteristics of vegetative growth, photosynthesis pigments and stomata characteristics of cowpea plants. The $\mathrm{I}^{\mathrm{AA}}$ application had stronger effects on the photosynthesis pigments through increasing chlorophylls and decreasing total carotenoids. While, leaf area, nodules dry matter and leaves content of $\mathrm{K}$ and $\mathrm{Zn}$ affected more by $\mathrm{Z}^{\mathrm{S}}$ compared to the $\mathrm{I}^{\mathrm{AA}}$. 


\section{REFERENCES}

[1] A.N. Matlob, E. Sultan and K.S. Abdul, Vegetable Production, Dar Al-Kutub Publ., Mosul Univ., Iraq, 1989.

[2] R.G. Upadhyay and A. Singh, "Effect of nitrogen and zinc on nodulation, growth and yield of cowpea (Vigna unguiculata)", Legume Research, 39 (1), pp. 149-151, 2016. DOI: 10.18805/lr.v39i1.8880

[3] M.M. Patel, I.C. Patel, R.I. Patel and S. Acharya, "Effect of zinc and iron on yield and yield attributes of rainfed cowpea (Vigna unguiculata L. Walp), Annals of Arid Zone, 50(1), pp.17-19, 2011

[4] S. Kasturikrishna and I.P.S. Ahlawat, "Effect of moisture stress and phosphorus, sulphur and zinc fertilizer on growth and development of pea (Pisum sativum)", Indian Journal of Agronomy, 45(2), pp.353-356, 2000.

[5] R. Praveena, G. Ghosh and V. Singh "Effect of foliar spray of boron and different zinc levels on growth and yield of kharif greengram (Vigna radiata)", International Journal of CurrentMicrobiology and AppliedSciences,7(8), pp. 14221428, 2018.

[6] S. Dey, S. Prasad, P. Tiwari and P. Sharma "Effect of urea, $\mathrm{KCl}$, zinc placement and spray on growth of cowpea”, Journal of Pharmacognosy and Phytochemistry, SPI, pp. 971-973, 2017. www.phytojournal.com.

[7] A.W. Woodward and B. Bartel, "Auxin: Regulation, action, and interaction”, Annals Botany, 95, pp. 707-735, 2005.

[8] W.D. Teale, I. Ivan and K. Plame, "Auxin in action: Signalling, transport and the control of plant growth and development”, Nature Reviews Molecular Cell Biology, 7(11), pp.847-59, 2006. DOI: 10.1038/nrm2020

[9] P.J.J. Hooykaas, M.A. Hall and K.R. Libbenga, Biochemistry and Molecular Biology of Plant Hormones, Elsevier Science, The Netherlands. 1999.

[10] A.C. Wiedenhoeft, The Green World: Plant Nutrition, Chelsea House Publisher. USA, 2006.

[11] H.K. Lichtenthaler and A.R. Wellburn, "Determination of Total Carotenoids and Chlorophylls A and B of Leaf in Different Solvents”, Biochemical Society Transactions, 11, pp.591-592, 1983.

[12] D.J. Watson and M.A. Watson, "Comparative physiological studies on the growth of field crops. III- Effect of infection with beet yellows and beet mosaic viruses on the growth and yield of the sugar root crop”, Annals of AppliedBiology, 40(1), pp. 1-37, 1953.

[13] F.H. Al-Sahaf, Applied Plant Nutrition, Al-Hikma House, Baghdad, 1989.

[14] Y. P. Kalra, Reference Method for Plant Analysis. Taylor and Francis Group, LLC. 1998.

[15] A.O.A.C., Official Methods of Analysis. 11th Edition. Washington, D.C. Association of the Official Analytical Chemis. 1970.

[16] P. Rai and R.M. Mishra, "Effect of urban air pollution on epidermal traits of road side tree species, Pongamia pinnata L., Journal of Environmental Sciences and Toxicology \& Food Technology, 2(6), pp. 4-7, 2013.

[17] A.H. Reza, Design of Experiments for Agriculture and the Natural Sciences, Chapman \& Hall /CRC, New York, 2006.

[18] L. Su, G. Diretto, E. Purgatto, S. Danoun, M. Zouine, Z. Li, J. Roustan, M. Bouzayen, J. Giuliano, and C. Chervin, "Carotenoid accumulation during tomato fruit ripening is modulated by the auxin-ethylene balance", BMC Plant Biology, 15, pp.114, 2015. doi.org/10.1186/s12870-015-04954

[19] A.V. Barker and D.J. Pilbeam, Handbook of Plant Nutrition, CRC Press Taylor \& Francis Group, 2007.

[20] M.S. Nadergoli, M. Yarnia and F.R. Khoei, "Effect of Zinc and Manganese and Their Application Method on Yield and Yield Components of Common Bean (Phaseolus vulgaris L. CV. Khomein)”, Middle-East Journal of Scientific Research, 8(5), pp. 859-865, 2011.

[21] T.H. Amadi, Nutritional elements in agriculture, Baghdad University, Dar-Alhikma for printing and publishing, Baghdad, Iraq, 1991.

[22] Y. Mano and K. Nemoto, "The pathway of auxin biosynthesis in plants”, Journal of Experimental Botany, 63, pp. 2853-2872, 2012.

[23] J.E. Coleman, “Zinc proteins: Enzymes, storage proteins, transcription factors, and replication proteins”, AnnualReview Biochemistry, 61, pp.897-946, 1992.
[24] B.L. Vallee and K.H. Falchuk, "The biochemical basis of zinc physiology”, Physiology Review, 73, pp.79-118, 1993.

[25] I.H. Cakmak, H. Marschner and F. Bangerth, "Effect of zinc nutritional status on growth, protein metabolism and levels of indole-3-acetic acid and other phytohormones in bean (Phaseolus vulgaris L.), Journal of Experimental Botany, 40:405-412, 1989. (in: Barker and Pilbeam, 2007).

[26] A.S. Muhammed, "Effect of nitrogen fertilizer and spraying with Seaweed extract on growth and yield of Cucumber Cucumus sativus L.”, Diyala Agricultural Sciences Journal, 1(2), pp.134-145, 2009

[27] H.M. El-Saeid, S.D. Abou-Hussein and W.A. El-Tohamy, "Growth characters, yield and endogenous hormones of cowpea plants in response to IAA application", Research Journal of Agriculture and Biological Sciences, 6(1), pp. $27-$ 31. 2010.

[28] A.W. Woodward, B. Bartel, “Auxin: regulation, action, and interaction”, Annals of Botany, 95, pp. 707-735, 2005.

[29] Y. Pii, M. Crimi, G. Cremonese, A. Spena and T. Pandolfini, "Auxin and nitric oxide control indeterminate nodule formation”, BMC Plant Biology, 7:21, 2007. doi.org/10.1186/1471-2229-7-21.

[30] S. Ghosh,, C. Sengupta, T.K. Maiti and P.S. Basu. 2008. Production of 3-indolylacetic acid in root nodules and culture by a Rhizobium species isolated from root nodules of the leguminous pulse Phaseolus mungo. Folia Microbiology, 53: 351

[31] H.M.S. El-Bassiouny, and W.M. Shukry, "Cowpea growth pattern, metabolism and yield in response to IAA and biofertilizers under drought conditions", Egyptian Journal of Biology, 3, pp. 117-129, 2001.

[32] B. Hafeez, Y.M. Khanif and M. Saleem, "Role of zinc in plant nutrition- A Review", American Journal of Experimental Agriculture, 3(2), pp. 374-391, 2013.

[33] R. Prasad, Y. S. Shivay and D. Kumar, "Interactions of zinc with other nutrients in soils and plants - A Review”, Indian Journal of Fertilisers, 12 (5), pp. 16-26, 2016.

[34] S. Caglar, M. Sutyemez and S. Bayazit, "Stomatal density in some selected walnut (Juglans regia) types", Journal of the Faculty of Agricalture, 17(2), pp.169-174, 2004.

[35] E.M. Peksen, A. Peksin and C. Artik, "Comparison of leaf and stomatal characteristics in faba bean (Vicia faba L.)”, Journal of Biological Sciences,6(2), pp.360-364, 2006. 